\title{
DIRECT AND INDIRECT SPEECH ACTS IN POLITICIANS POSTS ON SOCIAL NETWORKS
}

\author{
Dalia Gulbinskienè $\dot{1}^{1}$ Tatjana Dubovičiene் $\dot{2}^{2}$, Rūta Lasauskienè $\dot{3}^{3}$ \\ ${ }^{1}$ Vilnius Gediminas Technical University, Saulètekio al. 11, LT-10223 Vilnius, Lithuania, \\ dalia.gulbinskiene@vgtu.lt \\ ${ }^{2}$ Vilnius Gediminas Technical University, Saulètekio al. 11, LT-10223 Vilnius, Lithuania, \\ tatjana.duboviciene@vgtu.lt \\ ${ }^{3}$ Vilnius Gediminas Technical University, Sauletekio al. 11, LT-10223 Vilnius, Lithuania, \\ ruta.lasauskiene@vgtu.lt
}

\begin{abstract}
The aim of this study is to present a detailed interpretation of the speech acts of posts and responses in the discourse analysis on Facebook. The research was handled on 20 posts of Donald Trump and Hillary Clinton and 20 responses of public people for each post. The conversations were between politicians and public people. The chosen methods were quantitative and qualitative analysis. The results indicate that the politicians' posts were direct rather than indirect in relation to the speech act. Then, the responses by the hearers were also more direct than indirect. Also, the results indicate that the usages of the locution, illocution and perlocution speech acts were followed by the politicians and the hearers successfully. The study suggests further research could be carried out in the field of politeness strategies in posts and responses.
\end{abstract}

Keywords: direct speech acts; indirect speech acts; locution; illocution; perlocution; conversational maxims.

\section{Introduction}

People are expressing themselves with their words. Actually, words refer to many meanings while explaining ideas, thoughts and concepts. People mostly mean much more than their words actually do. We sometimes mean something different from what our words actually say, as what it means refers to something else. A prominent researcher Grundy (2008) says that "what we mean by our words is more important than what our words mean".

The study which deals with the meaning of speech is referred to as pragmatics. It is a recent phenomenon in linguistics. In this paper adapts the main concepts of the most important pragmatists such as Searle, Austin, Grice and Leech. In that point, the main theories are going to be a perfect tool in the analysis of communication between politicians and public people on Facebook. People are communicating 
with each other, and internet is the best and easiest communication tool/way for people, who would like to share opinions and feelings with others around the world. Online communication is a form of communication, and people use many different tools on the Internet to share some thoughts or message to other people who are using the same tools. The data of the web-written communication, which is going to be gathered during the research procedure, is a great example of politicians' and public people manner to communicate.

Finally, the main obstacles in the analysis of the speech act are (a) distinguishing sentence meaning from speakers and hearers meaning, (b) investigating how we arrive at particular meanings, and (c) how speakers and hearers overcome the ambiguity in conversations. In order to provide an explicit rendering of structure and manner of web-based written communication, this quantitative and qualitative research is aimed at gaining a deep understanding of the "art" of public communication.

Research questions:

1. How are the conversational maxims reflected in the politicians' posts and public people's responses?

2. Do politicians and public people tend to be more direct or indirect in the speech acts on Facebook?

The aim and objectives of the research

In order to analyse politicians' and public people's communication on Facebook, this study aims to present a detailed interpretation of the speech acts of posts via discourse analysis. There are 6 objectives that should be followed for fulfilling the aim:

1. To indicate the most important theories and works in pragmatics for having tools to write the analysis.

2. To gather a web-written data of politicians' and public people's posts and responses to those posts on Facebook.

3. To analyse speech events of posts according to directness and indirectness.

4. To analyse speech events according to Grice's conversational maxims: quality, quantity, manner and relation.

\section{Research methods and procedures}

The study is based on qualitative and quantitative methods. Firstly, the data on posts and responses from Facebook between politicians and public people is randomly chosen for the aforementioned methods. 2 politicians were chosen who Donald Trump and Hillary Clinton. Then, 10 posts were chosen from each politician's Facebook account and for each post 1 response was chosen. Secondly, the web - written data of politicians was compiled, and the speech of posts and responses to these posts was categorized into two main sub-groups: positive responses and negative responses. Then, the collected posts and responses were analysed according to Grice's conversational maxims, directness/indirectness 
in the speech acts of posts and responses of those posts and locution, illocution, perlocution in the speech events.

For the qualitative results, discourse analysis (DA) is applied. The collected speech events of posts and responses are analysed thoroughly, according to conversational maxims and illocutionary force. This qualitative method will give an in-depth analysis of speech events of posts and responses. The quantitative method is aimed at the statistical measurement and the counting of directness/ indirectness frequency of occurrences in speech events of posts and responses.

\section{The scope of the research}

The speech events of posts and responses between politicians and public people are the main source form the qualitative discourse analysis. As Brown and Yule (1983) explained that discourse analysis is an analysis of language in use. Only recent linguists started looking in detail how the conversations are managed. As a result, the way politicians and public people use the English language while performing the posts and responses speech acts was analysed.

The discourse analysis is based on: (a) application of Grice's theory of conversational maxims such as manner, quantity, quality, and relation; and (b) analysis of directness and indirectness in the speech events. All these factors are helpful in comprehension and examination of how politicians and public people communicate on a Facebook website. Due to the restricted scope of the present study, only indicated models of investigation are chosen. They seem to be more acceptable in terms of Facebook analysis due to the fact that the discourse is written and the conversations have already taken place.

\section{Review of Literature}

This research paper is generally based on pragmatics. In addition to that, professor of theoretical linguistics Huang $(2007,2)$ gives brief definition of pragmatics as "the systematic study of meaning by virtue of, or dependent on, the use of language."

Pragmatics deals with the aspects of language structure and language principles. Pragmatics includes some main topics such as speech acts, implicature, deixis and so on. In this research paper, speech acts will be analysed deeply. Pragmatics studies the relation between language and context that are encoded in the structure of language (Winarsih, 2009). According to Yule (1996, 3), pragmatics is related to the meaning of the study as communicated by a speaker and understood by a listener. In other words, pragmatics refers to the relation between linguistic forms of the speaker and hearer of these linguistics forms. Yule $(1996,4)$ states that pragmatics provide an advantage that says something about speakers' meaning what they planned while speaking, their aims and purposes and speakers` assumptions. 
What is more, a British philosopher Grice introduced pragmatics and his best-known theory conversational maxims. As Winarsih says, pragmatists can analyse the discourse by means of implicature or conversational principles of the kind illustrated by Grice's Cooperative Principle. Grice formulated a theory in terms of which he classified different sorts of conversational implications, and tried to explain how they arise and are understood. It is common knowledge, he asserted, that people generally follow certain rules for efficient communication. Davis (1998) says that according to Grice's rules included one general 'principle of cooperation', and four 'maxims' specifying how to be cooperative:

The cooperative principle; contribute what is required by the accepted purpose of the conversation.

The maxim of quality: Make your contribution true, so do not convey what you believe false or unjustified.

The maxim of quantity: Be as informative as required, neither more nor less so.

The maxim of relevance: Be relevant.

The maxim of manner: Be perspicuous, avoid obscurity and ambiguity, and be brief and orderly.

The speech acts are the form of communication and self-expression. In general, speech act theory is the language of human utterances. Statement-making looks like the typical use of language, but there are kinds of things we could do with words. First of all, the term speech act was described by one of the founders of pragmatics Austin in 1962 and the term was developed by the philosopher of language Searle in 1969. British philosopher Searle (2002) describes the term speech acts as the basic units of linguistic interaction. In addition to that Yule $(1996,134)$ explains speech act theory as "an action performed by the use of an utterance to communicate". We could ask questions by using language, and then we could make an offer and so on. Speech act is the performance of many acts, noticeable by person's intention that made the speech. Generally, speech acts are kind of acts of communication with other people. There are many various ways to make a meaningful sentence which a speaker can express.

Politeness refers to good communicative relations of a single person, and with other people as well. As human beings, people are not born polite but people gain it by learning. People come from different cultural environment or different nations and interact between themselves using online communication tools such as Facebook. At this point, this part investigates the politeness principles and how people choose to speak, and how audiences react to their speech.

First of all, politeness is a pragmatic aspect which is an important interaction for the human life. The description of politeness is "showing awareness of another person's face" (Yule, 1996). Also, politeness might be defined as showing good manners towards others. Many theorists explained the meaning of politeness within the topic of politeness principle. Many years ago, Lakoff, Brown, Levinson and Leech studied the principles of politeness. According to Brown and Levinson (1987), 
everyone has a public self-image, which has relation to emotional and social sense of self and expects everyone else to recognize. Politeness refers to the common notion of the term, that is, the way politeness manifests itself in communicative interaction. Politeness is one of the constraints of human interaction, their purpose is to consider other's feelings, establish levels of mutual comfort, and promote rapport. Politeness is what we think to be an appropriate behaviour in particular situations in an attempt to achieve and maintain successful social relationships with others (Lakoff 1972) (Ilmu, 2014).

On the other hand, another important specialist and linguist Leech explains politeness principle. Leech says politeness principle is a type of behaviour that allows the participants to engage in a social interaction in an atmosphere of relative harmony. In stating his maxims, Leech uses his own terms for two kinds of illocutionary acts. He calls representatives "assertives", and calls directives "impositives". According to Yule, politeness is the awareness of another face. The word "face" in this case refers to the public self-image of a person (Ilmu, 2014).

When people communicate with each other, they sometimes do not express what they would like to say directly. In addition to that, they use indirect speech acts while they are speaking. Hence, there are two types of speech acts: direct and indirect speech acts. According to Yule $(1996,54)$, there are three basic sentence types: declarative, interrogative and imperative. There is a relation between these sentence types with three general communicative functions: statement, question and request.

Yule $(1996,55)$ states that if there is a direct relationship between functions and structures, it is called a direct speech act. If there is an indirect relationship between functions and structures, it is called an indirect speech act. As explained in the examples above, a declarative sentence refers to direct speech act statement. However, declarative sentence refers to make a request for indirect speech act statement.

- The declarative type of sentence is a speech act of making statement.

- The interrogatives type of sentence is a speech act of making request.

- The imperative type of sentence a speech act of giving an order a directive.

To conclude, the direct speech act explains as locution of the speech act and it identifies the illocution. If the locution does not identify the illocution of a speaker's utterance, it is an indirect speech act. As a result, Yule $(1996,56)$ states that "indirect speech acts are generally associated with greater politeness in English than direct speech acts. In order to stand why, we have to look at a bigger picture than just a single utterance performing single speech act."

\section{Findings and Discussions}

This study is a qualitative and quantitative analysis. Firstly, posts by politicians, as well as responses to those posts were gathered from the social 
network which is Facebook. The data (see Appendix 1) contained real-time posts and responses to those posts on the website. Posts were taken from Facebook status updates of politicians and responses to these posts were taken from comments to the posts.

First, we chose 10 Donald Trump's posts and 10 Hillary Clinton's posts on their Facebook accounts and for each post we chose 1 response. Secondly, the web written data of politicians was compiled, and the speech of posts and responses to these posts were categorized into two main sub-groups: positive responses and negative responses. Thirdly, the speech events were analysed according to (a) Grice's conversational maxims: quality, quantity, manner and relation, (b) directness/ indirectness in the speech acts of posts and responses of those posts and (c) locution, illocution, perlocution in the speech events.

Concerning the posts which were negative responses, there were 23 direct posts, 2 indirect and 0 mixed posts which consisted of two speech acts of posts: direct followed by indirect or vice versa. The public people were direct (23) and indirect (2) in performing speech acts of posts when they were negative responses. In total, there were 46 direct, 4 indirect and 0 mixed speech acts of posts. As a result, the politicians and public people were equal in the acts of posting when they responded negatively.

Considering the directness and indirectness of speech acts, when they were positively responded, there were 24 direct, 1 indirect and 0 mixed (direct + indirect) speech acts in the posts. The politicians and common people had equal tendency to perform a mixed kind of posts: direct posts followed by indirect posts or vice versa. In the positive responses of posts, the politicians were indirect (1) in considering posts, and only 0 times people used a mixed type of consideration. All in all, the politicians and public people were mostly indirect in the speech acts of posts when they were positively responded.

Finally, the total amount of direct and indirect speech acts is indicated in the table 8 . The results suggest that the politicians and public figures were direct, with the total of 95 speech acts, and indirect, with the total of 5 speech acts, in performing the speech acts of posts and responding to these posts. The mixed type of performing speech acts was never used, with only 0 speech acts in total.

\section{Positive Responses}

1. Donald Trump: My Administration HEARS YOUR VOICE and HAS YOUR BACK. We are fighting to give every American a future of dignity, purpose, and pride. AMERICAN SPIRIT is back!

A: Keep up the GREAT work. They keep trying to keep you down but stay ahead of them and know that if you need help we got your back!!!

The first post has the $45^{\text {th }}$ President of United States Donald Trump performing a direct speech act in this post. The form of the utterance is declarative and the 
function is to show how the speaker cares about the situation of the country. Also, the speaker gives the message in a grammatically correct construction and uses capital letters to show the importance of the words. In addition to that, the speaker (Donald Trump) uses positive face and his utterance is relevant with perlocutionary speech act. In this way, the speaker demonstrates the effect upon hearer. Hereby, the hearer (A) understands what speaker wants to say and gives his message in a positive way. The hearer (A) performs a direct speech act. The hearer utterance is a type of imperative sentence speech act, and it gives an order to the speaker and confirms his message. The hearer gives positive response to the speaker, what the speaker wants to hear. Also, when we analyse Trump's post, the Grice's maxims are obvious in his message:

- The maxim of manner: Trump is brief and clear.

- The maxim of relation: Trump is relevant and he just talks about the progress of the country and doing best things for citizens as a president of the country.

In addition to that, politeness is bald off record. There is a social difference between the speaker and the hearer in the aforementioned presidential post; it shows the use of the second person pronoun 'your'.

2. Donald Trump: We MUST stop the massive inflow of drugs and people. Border Patrol Agents (and ICE) are GREAT, but the weak Dem laws don't allow them to do their job. Act now Congress, our country is being stolen!

A: $100 \%$ AGREE! This is most important issue of the day for me. If we don't stop this invasion we will lose our wonderful nation. Believe it people. It will be Europe and the refugees all over and who will support these people. YOU WILL.

In the utterance of the speaker (Donald Trump), there is a direct speech act. The speaker performs illocutionary speech act and it is an example of the directives according to Searle's classification of the illocutionary speech acts. The aim of the directive speech act in this post of the speaker is to demonstrate that something is to be done for the country. Moreover, the hearer (A) performs very positive face saving act and confirms the message of the speaker. The hearer uses capital letters and exclamation mark like speaker. It shows the importance of the words. Also, the speaker post has the Grice's conversational maxims:

- The maxim of quantity: Trump's contribution is informative; he conveys to the hearer what they should do for situation.

- The maxim of manner: Trump is clear and orderly while conveying his message.

- The maxim of quality: Trump is very exact bout the main topic.

3. Donald Trump: It's time to REBUILD, and we will do it with American WORKERS, American GRIT, and American PRIDE!

A: We will rebuild thanks to a great President who loves his Country which is the greatest Country on earth.

The speaker (Donald Trump) performs direct speech act and this type is declarative. As usual, the speaker uses capital letters to show the importance of the 
word and how meaningful a word is for him and the hearer. The act of illocution is performed successfully, and the speaker commits the hearer to rebuild the country with Americans. Thus, the function of the illocutionary act is commisive. Moreover, the post has a positive politeness strategy. Trump performs the strategy of communicating to the hearer's wants. In this way the hearer (A) performs positive response. Both post and response perform on record. The hearer (A) performs the utterance in an expressive way. All the conversational maxims have been followed in this speaker's post and the hearer's response:

- The maxim of quantity: Trump talks about rebuilding the country. $\mathrm{He}$ informs the hearer that he will work on it with all of the American workers.

- The maxim of quality: Trump is encouraging the hearer, and the hearer responds to his post by thanking and praising him.

- The maxim of manner: Here, Trump is clear enough and brief.

- The maxim of relation: The speaker and the hearer are relevant to the subject.

4. Donald Trump: I am pleased to announce that I intend to nominate highly respected Admiral Ronny L. Jackson, MD, as the new Secretary of Veterans Affairs. In the interim, Hon. Robert Wilkie of DOD will serve as Acting Secretary.

A: I guess think President is perfect and amazing absolutely excellent. The President trump wants to put the right people in the right place at the right time and that could change and bring fantastic excellent job in our government.

Again, the speaker performs direct speech act and the function is declarative. The declarative speech act changes the situation by speaker's utterance. The speaker performs the change by appointing and nominating. Also, while performing the illocutionary speech act, the speaker uses the collaborative type of illocutionary force, according to Leech's classification. The speaker announces the new appointment. Moreover, the speaker (Donald Trump) uses face saving act while announcing new assignment. The hearer (A) responds to the face saving act, and the message is the direct speech act. In addition to that, the hearer performs illocutionary speech act and it is a type of expression. The hearer shows the feelings about the speaker's message by thanking. The hearer uses strong adjectives meant to regard the speaker. Finally, the hearer (A) performs a face saving act by using a maxim of relation and performing an assertive speech act.

5. Donald Trump: A TOTAL WITCH HUNT!!!

A: WE THE PEOPLE SUPPORT OUR PRESIDENT - STAND STRONG PRESIDENT TRUMP

The speaker performs indirect speech act. The speaker wants to say something but he does not talk about a person, time or a place. The speaker performs off record speech act. The hearer (A) performs positive feelings to the speaker's message. Moreover, the hearer uses capital letters while conveying the message.

6. Hillary Clinton: To all the students who took part in \# NationalWalkoutDay yesterday:

Never let anybody tell you your voices don't make a difference. You're an 
inspiration to millions of Americans who know commonsense gun reform is long overdue. We are with you, and we will not give up.

A: Thank you so much for your leadership, Madam President. You continue to be an inspiration for us all. Re-elect Hillary Clinton 2020!

The speaker is the American politician Hillary Clinton who performs a direct speech act in her post. In the post, the speaker encourages the students and gives positive directives to them. While performing this speech, the speaker uses imperative sentence: "Never let anybody tell you your voices don't make a difference." In addition to that, the hearer shows positive emotions and a face-saving act. The hearer performs positive politeness strategy. The post and the respond follow some conversational maxims;

- The maxim of quantity: Clinton is quite informative.

- The maxim of manner: The speaker and the hearer are relevant.

- The maxim of manner: The both are brief, clear and orderly.

7. Hillary Clinton: The most important work of my life has been to support and empower women. I've tried to do so here at home, around the world, and in the organizations I've run. I started in my twenties, and four decades later I'm nowhere near being done. I'm proud that it's the work I'm most associated with, and it remains what I'm most dedicated to.

A: That show how a true president she is. She is the best woman in the world.

The speaker performs a direct speech act. The illocutionary speech act refers to the representative situation in her post. The hearer performs a direct speech act. The hearer (A) shows positive emotions to the speaker and it shows effect of perlocutionary speech act. Therefore the perlocutionary act is very positive on the hearer. The speaker uses some contracted form of the verbs such as; I've, it's and I'm while performing locutionary speech act.

8. Hillary Clinton: Before this year ends, I want to thank you again for your support of our campaign. While we didn't achieve the outcome we sought, I'm proud of the vision and values we fought for and the nearly 66 million people who voted for them.

I believe it is our responsibility to keep doing our part to build a better, stronger, and fairer future for our country and the world.

The holidays are a time to be thankful for our blessings. So let us rejoice in this season and look forward with renewed hope and determination.

I wish you and your family health, happiness, and continued strength for the New Year and the work ahead. I look forward to staying in touch in 2017. Onward!

With deep appreciation and warm wishes, I am,

Yours,

Hillary

A: You are a class act Hillary. You are also the People's President! Thank you for your inspiring message and lifetime of service to others.

- The speaker performs a direct speech act of her post. The speaker uses 
declarative sentences and gives information about the situation. Also, the speaker uses an expressive form of the illocutionary force while thanking the public people. Firstly, she just talks about the result of voting. Then the speaker tries to persuade the hearer by promising. The aim of the speaker is to provide the social goal with the hearer. What is more, the hearer shows expressive speech act while performing illocutionary force. Also, the speaker and the hearer use grammatically correct sentences from point of the locutionary speech act.

- The maxim of quantity: Clinton says she will keep working for America.

- The maxim of manner: Clinton is not brief. In addition to that the hearer is very brief and clear.

- The maxim of quality: Clinton is confident enough and she conveys what she believes.

- The maxim of relation: The speaker and the hearer are relevant.

9. Hillary Clinton: This week we lost 17 Americans in Parkland - the deadliest school shooting since Sandy Hook in 2012. Since then, 438 people have been shot and 138 killed in over 230 school shootings. That's 5 school shootings every month, 16 of which classify as "mass shootings." Now is the time to listen to the students, teachers, and parents demanding that we end this carnage once and for all with gun safety laws that keep guns out of the hands of those who shouldn't have them.

Mass shootings are not inevitable. The majority of Americans support common sense gun reform. Though we feel angry, heartbroken, even helpless now, we have the power to elect people who will protect lives, not gun sellers' profits. Remember these feelings in November, and VOTE.

A: This is leadership. She has never shied away from standing up to the gun lobby. True empathy and compassion. She is my President.

The speaker performs a direct speech act. Firstly, the speaker gives information with exact facts about the shooting. At the same time, the function is declarative of the direct speech. Also, the speaker uses the representative form of the illocutionary force. The speaker uses grammatically correct and full sentences. What is more, the speaker follows the maxim of quality, quantity and relation. Also the hearer follows the maxim of manner; the hearer is very brief and clear. The second part of the post, the speaker invites the people to protect the country and vote according to reality. Besides that, the hearer shows the feelings directly and encourage the speaker's ideas. So it shows the perlocutionary speech act of the post on the hearer.

10. Hillary Clinton: During an interview last week with an Indian news publication, I was asked about 2016, and whether Trump is the "virus" or a "symptom" of something deeper going on in American society. Like most Americans, people overseas remain shocked and dismayed at what they are witnessing daily.

My first instinct was to defend Americans and explain how Donald Trump could have been elected. I said that places doing better economically typically lean Democratic, and places where there is less optimism about the future lean 
Republican. That doesn't mean the coasts versus the heartland, it doesn't even mean entire states. In fact, it more often captures the divisions between more dynamic urban areas and less prosperous small towns within states. As I said throughout the campaign, Trump's message was dark and backwards looking. I don't need to list the reasons, but the foundation of his message, "Make America Great AGAIN" suggests that to be great we have to go back to something we are no longer. I never accepted that and never will.

A: As always, your words were misinterpreted and misquoted. Wasn't the first time, won't be the last. Thank you for this post and clarification, Madam Secretary. We are still with you.

The speaker performs a direct speech act and the function of the speech act is declarative. The post of the speaker refers to the representative illocutionary speech act. The speaker tries to correct her opinion which understood wrong. While performing the utterance the speaker uses on record speech act. Moreover, the speaker violates the maxim of manner but she follows the maxim of quantity and she is as informative as required. Then, the hearer responds positive message to the speaker what she expects from hearers. Therefore the perlocutionary speech act shows the effect of the post on the hearer. While analysing the locutionary speech act, some sentences have initial ellipsis in the hearer's respond and grammatically corrected construction should be; "it wasn't the first time and it won't be the last." Grice's maxim;

\section{Negative Responses}

11. Donald Trump: A perfectly executed strike last night. Thank you to France and the United Kingdom for their wisdom and the power of their fine Military. Could not have had a better result. Mission Accomplished!

A: I disagree with your decision Trump. War is never the solution. Your leadership is failing. We are democratic-republic, not a autocracy.

The speaker performs a direct speech act about the situation. First of all the speaker explains his ideas and shows the feeling by using an expressive form of illocutionary force. Then the speaker observes all conversational maxims;

- The maxim of quantity: Trump talks about the strike and thanks to other countries.

- The maxim of manner: Trump is clear and orderly while posting his message. Also the hearer is very brief and clear while performing own ideas.

- The maxim of quality: Trump is confident.

- The maxim of relation: Trump is relevant to the main topic that is about the power of the military.

The hearer performs a direct speech act. Hearer violates the maxim of manner. The hearer is not very relevant in the response. He talks about the war and then the just talks about the character of the speaker. What is more, the hearer is not as informative as required while performing the maxim of quantity. In addition to 
that, the hearer has a mistake while writing the response. The grammatically correct construction should be: "we are a democratic republic, not an autocracy." What is more, the hearer performs a face threating act to the speaker: "your leadership is failing."

12. Donald Trump: Our relationship with Russia is worse now than it has ever been, and that includes the Cold War. There is no reason for this...we need all nations to work together. Stop the arms race?

A: President Trump, please remember the promises you made to us in 2016: America First, and no more wars. No more wars for globalists. We do not wanna war!

The speaker performs a direct speech act. Trump violets the maxim of quantity and he does not talk about the deep information the situation of Russia and America, just introduce the relationship and Cold War. The speaker uses elliptical sentence while performing his utterance from point of the locutionary act. The second part of the post, the speaker uses an interrogative direct speech act form. The hearer performs a direct speech act and tries to persuade the speaker by performing the hearer uses the verb 'wanna', that is contracted form of the verb and it is an informal verb in this response. The hearer observes the maxim of manner so the hearer is clear and orderly.

13. Donald Trump: Russia vows to shoot down any and all missiles fired at Syria. Get ready Russia, because they will be coming, nice and new and "smart!" You shouldn't be partners with a Gas Killing Animal who kills his people and enjoys it!

A: No way. What kind of stupid, crazy and childish post is this! Holy hell, this is so unreal, joking and bragging about missile launches on Facebook and Twitter. I don't even know what to say anymore.

The speaker performs a direct speech act. The form of the illocutionary force is directives. The speaker's aim is to show the hearer to do something about a Gas Killing Animal. Also, the hearer performs a direct speech. Besides that, the hearer shows a face threating act towards to the speaker. The hearer completely disagrees with the speaker and performs own ideas of negative politeness strategy. The hearer uses illocutionary force and the forms are conflicting by use of cursing. The perlocutionary act of the post is not very successful what the speaker expects from the hearer.

14. Donald Trump: I am doing everything I can to fight for the agenda that millions and millions of Americans voted for, but we must keep pushing Congress to build the wall. ADD YOUR NAME!

A: No wall. No military presence at our border. We are not mid-20th century East Germany. Plus didn't you promise your voters that tax payers would not foot the bill for your ridiculous wall?

The speaker performs a direct speech act. The speaker gives the directive to the hearer; "add your name" and while performing this utterance he uses capital letters to show the importance of the situation. What is more, the illocutionary meaning of this post, the speaker expects that the hearer shows a positive attitude 
towards his message. The hearer performs a negative response to the speaker and uses direct speech act. Besides that, the hearer uses an elliptical sentence such as; "no wall. No military presence at our border." The sentence structure is not correct in the response of the hearer. Also, the effect of the post is negative in relation to the hearer while performing a perlocutionary speech act.

15. Donald Trump: I went to California and saw the border wall prototypes. We NEED the wall to STOP illegal immigration. If we lose our borders, we lose our country! Tell Senate to BUILD THE WALL.

A: The wall is a stupid, environmentally destructive idea except in only a few circumstances. Be smart and invest in technology and personnel instead.

As for the previous post, the speaker Trump performs a direct speech act. While performing this speech act, the aim of the speaker is to show or to tell to vote for something. Therefore, the form of the illocutionary speech act is direct. For the response of this post, the hearer performs directly the opinions. The hearer uses a face threating act and negative politeness strategy. The hearer observes the behabitive form of the illocutionary speech act by using cursing; "the wall is stupid." What is more, some conversational maxims are followed in the post and response;

- The maxim of manner: The hearer is brief and clear.

- The maxim of relation: The hearer's response is relevant with the post of speaker.

- The maxim of quantity: The speaker violates the maxim of quality; from the post, he does not give deep information as required.

16. Hillary Clinton: In honor of \#InternationalWomensDay, I want to celebrate some of the women and girls who inspire me every day. These women resist inequality, insist on a better world, persist against all odds, and enlist others in our shared fights.

A: Hillary!!! NO MAN told me how to vote or who to vote for!! This is not the 1800 s or early 1900 s!! We women voted our own minds and with free will. I would have voted for Trump when he was going to fun in 2000!! You never had a chance with me!!! Stop with the blame game!! You are a rotten example of women in this country!!

The speaker performs a direct speech act and congratulates on the international women days. So the speaker uses the form of expressive illocutionary force. Besides that, while using perlocutionary speech acts, the speaker performs her ideas about women, but the effect on the hearer is not successful. What is more, the speaker uses a face-saving act and politeness strategy very orderly. The hearer performs a direct speech act. The hearer's response includes the negative politeness strategy and the hearer shows a face threating act to the speaker. Also, the hearer violates the maxim of manner: the hearer's response is very long. What is more, the hearer uses some dates in the response and uses many exclamation marks to refer to the feelings.

17. Hillary Clinton: Las Vegas, we are grieving with you - the victims, those who lost loved ones, the responders, and all affected by this cold-blooded massacre. 
The crowd fled at the sound of gunshots.

Imagine the deaths if the shooter had a silencer, which the NRA wants to make easier to get.

Our grief isn't enough. We can and must put politics aside, stand up to the NRA, and work together to try to stop this from happening again.

A: This isn't about the NRA! This is about bad people doing horrific things! Can't you leave politics out, even for a moment?

The speaker performs a direct speech act. Also, the hearer performs a direct speech act yet the opinion of the hearer is negative, and the hearer uses a face threating act towards the speaker. Moreover, the hearer uses interrogative sentences in relation to the speaker. Besides that, the speaker uses imperative and grammatically correct sentences. Also, Clinton uses a contracted form of the verb: isn't instead of is not. The illocutionary form of the post is an expressive speech act. Also, the hearer asks the speaker a question and it is in the form of direct illocutionary force example in this response. Therefore, there is no effect on the hearer of this post by the perlocutionary act.

18. Hillary Clinton: Scripture tells us: Let us not grow weary in doing good, for in due season, we shall reap, if we do not lose heart.

A: You didn't lose because you're a woman. You lost because of all the horrible things you did. Trump might have said a couple bad things, but you did many bad things. You spend our enemies money bashing him and he funded himself.

The speaker performs both direct and indirect speech acts. Clinton cites an utterance from the scripture and tries to give a message to the people. The speaker violates the maxim of quantity, because she is not informatively deep. The speaker is a representative when he is performing an illocutionary speech act. Then the hearer performs a direct speech act and expresses the opinion in a negative way. The hearer uses a face threating act. On the other hand, the speaker uses correct sentence structure. In addition, the hearer is quite successful, but from the point of view of a perlocutionary speech act, the speaker is not very successful, because the post does not make sense to the hearer.

19. Hillary Clinton: I've never been able to resist story time with my grandchildren, Charlotte and Aidan. That's why I was inspired to release my new children's book, "It Takes A Village." I hope you share it with the kids in your life, and enjoy it as much as we have!

A: A must read for Trump. It's even on his grade level like you!

The speaker performs a direct speech act and she is quite informative about the situation. The speaker expresses her best wishes to the hearers, so the speaker uses the form of expressive illocutionary speech act. Also, the speaker locutionary act is grammatically correct, and she uses just the contracted form: I've instead of I have. The act of perlocution is not very effective in relation to the hearer. The response from the hearer shows negative ideas. The hearer uses an elliptical sentence at the beginning of the response from the locutionary speech act point of view. 
20. Hillary Clinton: Last night, I congratulated Donald Trump and offered to work with him on behalf of our country. I hope that he will be a successful president for all Americans. This is not the outcome we wanted or we worked so hard for, and I'm sorry we did not win this election for the values we share and the vision we hold for our country. Donald Trump is going to be our president. We owe him an open mind and the chance to lead.

A: 1t is the best choice for USA! not you of course ! You are bad one for America

The speaker performs a direct speech act and expresses her ideas about the election of president Trump. The speaker observes some conversational maxims, such as the maxim of quality; the speaker makes her contribution and she posts what she believes. Then she follows the maxim of relation; Clinton is sure about the situation. Moreover, from the locutionary point of view, the speaker uses a meaningful linguistic expression. Also, the speaker uses illocutionary speech act, the form is expressive: she congratulates Trump. On the other hand, the effect of the post on the hearer is not very positive. Besides that, the hearer performs a face threating act. In addition to that, the hearer is not fluent or good in English.

\section{Conclusions}

This paper handled the analysis of posts by chosen politicians and responses to those posts. The focus was the speech acts of posts and responses. The data collection consists of different posts and responses, and their manner. Furthermore, the hearers used direct speech act and their sentence structures were elliptical. In addition, the hearers used a great number of abbreviations. The analysis of posts and responses to them allows describing hearers as generally colloquial and informal in their writing style while responding to posts by politicians on Facebook.

One part of the result consists of positive responses and negative responses to the politicians' post. The hearers used a face saving act while performing positive responses, and a face threating act while performing negative responses.

The politicians' posts could be defined as direct rather than indirect within the act of speech. There were 47 direct posts and only 3 indirect posts in the politicians' posts. Then, the responses to the posts were also more direct than indirect. There were 48 direct responses and only 2 indirect responses to the politicians' posts. Totally, 95 messages were direct and just 5 messages were indirect in the research study. Even while performing negative responses, the hearers were using direct speech acts and face threating acts. This explains the usage of the face threating act while performing negative opinions to the speaker. According to directness and indirectness, the posts and responses were equal.

While analysing the posts and responses, conversational maxims, introduced by Grice, were observed. The hearers frequently violated the conversational maxims. Overall, the maxims of quality and quantity were violated by hearers. In addition to 
that, some hearers' responses were followed by some conversational maxims. The maxims of relation and manner were followed by hearers most frequently.

Altogether, the politicians observed the conversational maxims in direct speech acts. They were clear, orderly, truthful and relevant while posting their messages to the people. As a result, the politicians followed all the conversational maxims in their direct speech acts. Furthermore, the usage of the locution, illocution and perlocution speech acts was followed by politicians and hearers successfully.

Finally, as the wished and examined objectives were completed by successfully utterance analysis, some further research should be carried out in the field of speech acts of posts and responses. It could be based on the analysis of politeness strategies and comments as responses language usage of speech acts.

\section{Literature}

Adwan, O. (2015). PRAGMATIC ANALYSIS OF SPEECH ACTS IN HEADLINES OF "THE INDEPENDENT" NEWSPAPER. A Thesis Submitted in Partial Satisfaction of the Requirements for the Degree Master of Arts. Suleyman Demirel University.

Al-Ameedi,R. \& Khudhier,Z. (2015). A Pragmatic Study of Barak Obama's Political Propaganda. Journal of Education and Practice. 20 (6)

Austin, J. L. (1962) How to Do Things with Words, Cambridge, Mass.: Harvard University Press.

Bach, K. (1979). Speech Acts. Routledge Encyclopedia of Philosophy entry.

Bach, K. (1994). Conversational implicature', Mind \& Language 9: 124-62.

Bach, K. and R. M. Harnish (1979). Linguistic Commuication and Speech Acts, Cambridge, Mass.: MIT Press.

Brown, K. (Ed.). (2006). Encyclopedia of Language and Linguistics. UK: Oxford. [second edition, volume 10]

Crystal, D. (2001). Language and the Internet. UK: Cambridge University Press.

Crystal, D., (1985). A dictionary of linguistics and phonetics. 2nd edition. New York: Basil Blackwell.

Davis, A. W. (1998). Implicature. In Routledge Encyclopaedia of Philosophy; Philosophy of language, (pp. 89-93). London and New York: Routledge.

Finch, G. (2003). How to Study Linguistics. A Guide to Understanding Language. Great Britain: Palgrave Macmillan. [second edition]

Grice, H. P. (1989) Studies in the Way of Words, Cambridge, Mass.: Harvard University Press.

Griffiths, P., (2006). An Introduction to English Semantics and Pragmatics. Edinburgh Textbook on the English Language. Second Edition. 174(141-142)

Grundy, P. (2008). Doing Pragmatics. UK: Hodder Education. [third edition] 
Halpern, D., \& Gibbs, J. (2013). Social media as a catalyst for online deliberation? Exploring the affordances of Facebook and YouTube for political expression. Computers In Human Behavior, 29(3), 1159-1168.

Huang, Y. (2007). Pragmatics. Oxford Textbooks in Linguistics. Oxford University Press

Ilmu, G. (2014). Pragmatic Politeness and Interaction. Learning by doing. Retrieved from https://febry23.wordpress.com/2014/01/10/pragmatic-politenessand-interaction/

Justova, V.,(2006). Direct and Indirect Speech Acts in English. Major Bachelor's Thesis. Masaryk University in Brno

Kristensen, J. B., Albrechtsen, T., Dahl-Nielsen, E., Jensen, M., Skovrind, M., \& Bornakke, T. (2017). Parsimonious data: How a single Facebook like predicts voting behavior in multiparty systems. Plos ONE, 12(9), 1-12.

Leech, G. (1983). Principles of Pragmatics. England: Longman Linguistics Library

Leech, G. (2014). The Pragmatics of Politeness. Oxford University Press: Oxford Studies in Sociolingistics. 337 pp.

Leech, G., Svartvik, J. (1994). A communicative Grammar of English. New York: Longman. [second edition]

Levinson, S. (1983) Pragmatics. Cambridge : Cambridge University Press

McKay, S.L. (1996). Sociolinguistics and Language Teaching. USA: Cambridge University Press.

Oishi, E., (2006). Austin's Speech Act Theory and the Speech Situation. Esercizi Filosofici (1-14)

Phillips, D. (1998). Emotive meaning. In Routledge Encyclopaedia of Philosophy; Philosophy of language, (pp. 76-77). London and New York: Routledge.

Searle, J. (1969) Speech Acts: An Essay in the Philosophy of Language, Cambridge, Eng.: Cambridge University Press.

Searle, J.R. (2002). Speech Acts, Mind, and Social Reality. From Discussions with John R. Searle. Grewendorf, G., Meggle, G. (Eds.). The Netherlands: Kluwer Academic Publishers.

Sørensen, M. P. (2016). Political conversations on Facebook - the participation of politicians and citizens. Media, Culture \& Society, 38(5), 664-685.

Vitkauskiené, J. (2010, January 4). A Way of Analyzing Perlocutionary Speech Acts.

Winarsih,S. (2009). The Cooperative and Politeness Principles in Radio Broadcasting Conversations. Universitas Kanjuruhan Malang. 31(1).

Yule, G. (1996). Pragmatics. Oxford Introductions to Language Study. New York: Oxford University Press 


\title{
TIESIOGINE் IR NETIESIOGINE் KALBINE் VEIKLA POLITIKŲ İRASUUOSE SOCIALINIUOSE TINKLUOSE
}

\author{
Dalia Gulbinskienè $\dot{1}^{1}$ Tatjana Dubovičienè $\dot{e}^{2}$, Rūta Lasauskiené $\dot{3}^{3}$ \\ ${ }^{1}$ Vilniaus Gedimino technikos universitetas, Sauletekio al. 11, LT-10223 Vilnius, Lietuva, \\ dalia.gulbinskiene@vgtu.lt \\ ${ }^{2}$ Vilniaus Gedimino technikos universitetas, Saulètekio al. 11, LT-10223 Vilnius, Lietuva, \\ tatjana.duboviciene@vgtu.lt \\ ${ }^{3}$ Vilniaus Gedimino technikos universitetas, Sauletekio al. 11, LT-10223 Vilnius, Lietuva, \\ ruta.lasauskiene@vgtu.lt
}

\section{Santrauka}

Žmonès išreiškia savo mintis žodžiais. Iš tikrųjų žodžiai turi daugybę reikšmių, kai vartojami idèjoms ir mintims paaiškinti. Žmonès turi omenyje daug daugiau, nei jų žodžiai iš tikrujų reiškia. Kartais mes turime galvoje kažką kita, nei mūsų žodžiai pasako. Vienas svarbių šios srities mokslininkų Grundy (2008) sako, kad „mūsų intencija išsireikšti yra svarbesnė už tai, ką reiškia žodžiai patys savaime“. Mokslas, kalbantis apie kalbos prasmę, vadinamas pragmatika. Tai naujausias kalbotyros fenomenas. Šis rašto darbas - bandymas praktiškai pritaikyti tokių pragmatikų kaip Searle, Austin, Grice ir Leech pagrindines sąvokas. Pagrindinès šios srities teorijos yra puikus įrankis analizuojant politikų ir žymių veikejjų bendravimą „Facebook“ tinklalapyje. Internetinio bendravimo duomenys, kurie bus renkami atliekant tyrimo procedūrą, yra puikus pavyzdys, kaip politikai ir visuomenè gali bendrauti. Pagrindinès kalbos akto analizès kliūtys yra: a) sakinio reikšmès ir kalbėtojų/klausytojų prasmès atskyrimas; b) konkrečių reikšmių pasiekimo eigos analizė ir c) būdų, kaip kalbėtojai ir klausytojai įveikia pokalbių dviprasmiškumą, tyrimas.

Šio darbo tikslas - pristatyti išsamų kalbinių aktų tyrimą diskursų analizejje. Tyrimo tikslas buvo pateikti svarbiausias pragmatikos teorijas, kad atsirastų priemonè rašytinei analizei atlikti. Buvo pasirinktos politikų Donaldo Trumpo ir Hillary Clinton paskyros ir iš kiekvienos politiko „Facebook“ paskyros - 10 pranešimų, kiekvienam pranešimui buvo pasirinktas 1 atsakymas. Antra, buvo surinkti žiniatinklio įrašai apie politikus, o jų pranešimai suskirstyti ị du pagrindinius pogrupius - teigiami ir neigiami atsakymai. Trečia, kalbos ìvykiai buvo analizuojami pagal (a) Gritso pokalbio principus: kokybę, kiekį, būdą ir ryšị; (b) diskretiškumą/ nediskretiškumą pranešimų kalbos aktuose ir atsakymuose.

Tyrimas pagrịstas kokybiniais ir kiekybiniais metodais. Pirma, iš šių dviejų metodų atsitiktine tvarka renkami „Facebook“ pranešimų ir politikų, viešųjų asmenų, atsakymų duomenys. Kokybiniams rezultatams taikoma diskurso analizè (DA). Surinkti pranešimų ir atsakymų kalbos įvykiai yra analizuojami detaliai pagal pokalbių maksimas ir kalbos aktus. Šis kokybinis metodas padès išsamiai išnagrinèti pranešimų ir atsakymų kalbos ịvykius. Kiekybinis metodas skirtas statistiniam matavimui ir tiesioginių ar netiesioginių ịvykių dažnio skaičiavimui pranešimų ir atsakymų kalbos ịvykiuose.

Galiausiai buvo nagrinėti politikų ir viešųų asmenų tiesioginės kalbos veiksniai: apskritai politikų pranešimai buvo aiškūs, logiški, teisingi. Dèl to politikai ir viešieji asmenys dažniausiai sekè visus pokalbio principus tiesioginiuose kalbos aktuose. Be to, politikai ir klausytojai sẻkmingai sekè lokucijos, ilokucijos ir perlokucijos kalbos veiksnius. Politiku kalbos akto ịrašai buvo labiau tiesioginiai negu netiesioginiai. Tada atsakymai ị klausytoju klausimus taip pat buvo labiau tiesioginiai nei netiesioginiai kalbos veiksmai. 